\title{
PENGARUH PEMBELAJARAN FLIPPED CLASSROOM TERHADAP HASIL BELAJAR KALKULUS INTEGRAL MAHASISWA PENDIDIKAN MATEMATIKA
}

\author{
Marfi Ario $^{1 \varpi}$ dan Azmi Asra ${ }^{2}$ \\ ${ }^{1}$ Prodi Pendidikan Matematika, Universitas Pasir Pengaraian \\ ${ }^{2}$ Prodi Pendidikan Fisika, Universitas Pasir Pengaraian
}

\begin{tabular}{|c|c|}
\hline Info Artikel & Abstract \\
\hline $\begin{array}{l}\text { Sejarah Artikel: } \\
\text { Diterima 25Agt } 2018 \\
\text { Direvisi 4 Sept } 2018 \\
\text { Disetujui 29 Okt } 2018\end{array}$ & $\begin{array}{l}\text { This study was conducted with the aim to determine the effect of flipped classroom learning on the } \\
\text { results of learning the integral calculus material of mathematics education students. This research } \\
\text { is a quasi-experiment with the research design is a randomized control group posttest only design. } \\
\text { The populations of this study were } 27 \text { students who took integral calculus courses divided into two } \\
\text { classes. The research sample was taken using saturated sampling technique. Students in the } \\
\text { experimental class received flipped classroom learning, while students in the control class received } \\
\text { direct learning. Research data in the form of student integral calculus learning outcomes obtained } \\
\text { through test techniques with essay questions. The test results showed the average student learning } \\
\text { outcomes in the experimental class was } 74.57 \text { and in the control class was } 55.83 \text {. This research data } \\
\text { was analyzed using the Mann-Whitney test. The analysis shows that there is an effect of flipped } \\
\text { classroom learning on the results of learning the integral calculus material of mathematics } \\
\text { education students. }\end{array}$ \\
\hline
\end{tabular}

\begin{abstract}
Abstrak
Penelitian ini dilakukan dengan tujuan untuk mengetahui pengaruh pembelajaran flipped classroom terhadap hasil belajar materi kalkulus integral mahasiswa pendidikan matematika. Penelitian ini merupakan quasi exsperiment dengan desain penelitian randomized control group posttest only design. Populasi penelitian ini adalah mahasiswa yang mengambil mata kuliah kalkulus integral sebanyak 27 orang yang terbagi dalam dua kelas. Sampel penelitian diambil menggunakan teknik sampling jenuh. Mahasiswa di kelas eksperimen memperoleh pembelajaran flipped classroom, sedangkan mahasiswa di kelas kontrol memperoleh pembelajaran langsung. Data penelitian berupa hasil belajar kalkulus integral mahasiswa diperoleh melalui teknik tes dengan soal berbentuk uraian. Hasil tes menunjukkan rata-rata hasil belajar mahasiswa di kelas eksperimen adalah 74,57 dan di kelas kontrol adalah 55,83. Data penelitian ini dianalisis menggunakan uji Mann-Whitney. Hasil analisis menunjukkan bahwa terdapat pengaruh pembelajaran flipped classroom terhadap hasil belajar materi kalkulus integral mahasiswa pendidikan matematika
\end{abstract}




\section{PENDAHULUAN}

Matematika mempunyai peranan penting dalam kehidupan sehari-hari dan bidang ilmu lainnya (Fahrudhin, Zuliana, dan Bintoro, 2018). Pentingnya matematika salah satunya ditandai dengan diajarkannya matematika sejak dibangku Sekolah Dasar (SD) hingga perguruan tinggi. Salah satu mata kuliah matematika yang diajarkan di perguruan tinggi adalah kalkulus. Kalkulus memiliki cakupan materi yang sangat luas sehingga pengajaran kalkulus dibagi dalam beberapa matakuliah sesuai topik yang diajarkan. Salah satunya yaitu kalkulus integral yang diajarkan pada semester dua pada program studi pendidikan matematika Universitas Pasir Pengaraian.

Pemahaman kalkulus integral sangat penting bagi mahasiswa pendidikan matematika untuk dapat mengikuti perkuliahan lainnya dengan baik. Hal ini disebabkan karena banyak materi matematika khususnya pada penurunan rumus yang membutuhkan kemampuan mengintegralkan suatu fungsi. Oleh karena itu penguasaan mahasiswa terhadap kalkulus integral mutlak diperlukan.

Selain dari itu, mahasiswa pendidikan matematika diproyeksikan akan menjadi seorang guru matematika dikemudian hari. Salah satu kompetensi yang harus dimiliki guru adalah kompetensi profesional (UU No 14 tahun 2005). Kompetensi profesional merupakan kemampuan yang berkenaan dengan penguasaan materi pembelajaran bidang studi secara luas dan mendalam yang mencakup penguasaan isi materi kurikulum mata pelajaran di sekolah dan substansi keilmuan yang menaungi materi kurikulum tersebut serta menambah wawasan keilmuan bagi guru (Marhamah, 2016). Untuk menjadi guru matematika yang profesional maka mahasiswa calon guru matematika harus menguasai materi-materi matematika sekolah dengan baik (Ario, 2017). Salah satu materi matematika sekolah adalah integral yang diajarkan di tingkat Sekolah Menengah Atas (SMA). Atas dasar tersebut maka mahasiswa pendidikan matematika wajib menguasai materi kalkulus integral dengan baik.

Harapan agar mahasiwa memiliki penguasaan kalkulus integral yang baik ternyata tidak sesuai dengan kenyataan. Hasil ujian akhir mahasiswa pada mata kuliah kalkulus integral masih rendah dengan rata-rata penguasaan di bawah 50\% (sumber: data hasil ujian akhir semester mahasiswa semester 2 tahun ajaran 2016/2017). Hasil diskusi bersama dosen lain diperoleh informasi bahwa mahasiswa yang sudah memasuki semester 3 keatas selalu mengalami kesulitan jika diminta untuk mengintegralkan suatu fungsi.

Hasil refleksi peneliti terhadap pembelajaran selama ini ditemukan permasalahan yang menjadi salah satu penyebab utama rendahnya penguasaan materi kalkulus integral pada mahasiswa. Permasalahan tersebut adalah seringnya dosen kekurangan waktu dalam menjelaskan materi. Dalam satu pertemuan seringkali hanya sebagian materi yang tersampaikan. Hal ini disebabkan karena lambatnya mahasiswa dalam memahami materi yang diberikan. Hal ini dapat dimaklumi karena memang kampus ini bukan favorit bagi para siswa SMA, sehingga mahasiswa yang masuk ke kampus ini sebagian besar bukanlah siswa yang unggul saat di SMA. Dosen memberikan penjelasan secara pelan-pelan dan berulang untuk dapat dipahami mahasiswa. Pembelajaran seperti ini akhirnya membuat dosen tidak memiliki cukup waktu untuk bisa memberikan contoh-contoh soal yang terlalu banyak. Latihan yang diberikan juga terbatas. Bahkan materi yang diberikan tidak bisa terlalu luas dan dalam. Latihan-latihan yang lebih sulit akhirnya dijadikan tugas untuk dikerjakan mahasiswa di rumah. Namun pada pertemuan berikutnya, tugas yang diberikan tidak diselesaikan oleh mahasiswa dengan alasan mereka tidak mampu menyelesaikannya. Mahasiswa hanya bisa menyelesaikan soal-soal yang sama persis dengan contoh yang ada. Secara umum dapat dikatakan pembelajaran yang terjadi selama ini belum berjalan efektif.

Hal yang dapat dilakukan untuk mencapai pembelajaran yang efektif adalah dengan memilih dan menggunakan model pembelajaran yang tepat serta sesuai dengan materi yang diajarkan (Noviarny, Murtono, dan Ulya, 2018). Mencermati permasalahan tersebut maka diperlukan suatu jenis pembelajaran yang bisa memberikan kesempatan kepada dosen untuk menjelaskan materi secara detail dan dalam, mahasiswa bisa memperoleh contohcontoh soal yang bervariasi dengan tingkat kesulitan yang berbeda, serta bisa mengerjakan latihan yang cukup beragam. Untuk mensiasati hal tersebut maka perlu pembelajaran yang tidak hanya mengandalkan pertemuan di dalam kelas. Pembelajaran harus dibalik prosesnya. Pertemuan di kelas yang selama ini digunakan untuk menjelaskan materi diganti dengan pengerjaan latihan, diskusi dan mengeksplorasi materi pembelajaran. Sehingga kesulitan mahasiswa dalam mengerjakan tugas-tugas yang diberikan untuk dikerjakan di rumah dapat dibimbing oleh dosen karena kini tugas itu di 
kerjakan di kelas. Sedangkan pekerjaan rumah yang selama ini berupa latihan-latihan diganti menjadi memahami materi melalui penjelasan video yang dibuat oleh dosen. Sehingga mahasiswa dapat mendengarkan berkali-kali untuk memahami materi.

Proses pembelajaran seperti yang dijelaskan di atas disebut dengan pembelajaran Flipped Classroom. Flipped Classroom merupakan suatu strategi pembelajaran yang mengubah apa yang seharusnya dikerjakan di luar kelas oleh mahasiswa berupa penugasanpenugasan menjadi dikerjakan di dalam kelas dengan didampingi dosen dan apa yang seharusnya dikerjakan di dalam kelas berupa pengajaran dan penyampaian materi oleh dosen menjadi dikerjakan di luar kelas dengan menonton video pembelajaran yang telah disiapkan (Ridha, Setyosari, dan Kuswandi, 2016). Secara sederhana metode ini membalik cara pengajaran di kelas. Pada strategi ini, bahan pelajaran harus dipelajari oleh mahasiswa dirumah sebelum pembelajaran, sehingga di kelas dosen tidak lagi menjelaskan materi, tetapi langsung mengerjakan latihan soal atau aktivitas lainnya seperti debat, persentasi, diskusi, dan sebagainya (Chandra dan Nugroho, 2016).

Berdasarkan definisi pembelajaran flipped classroom, dapat dikatakan bahwa pembelajaran flipped classroom memuat dua aktifitas belajar yaitu di luar kelas dan di dalam kelas. Berdasarkan jenis kegiatan yang dilakukan di luar kelas dan di dalam kelas, Bioshop dan Verleger (2013) mendefinisikan model pembelajaran flipped classroom kedalam dua bagian, yaitu arti sempit dan arti luas. Dalam arti sempit, kegiatan flipped classroom di luar kelas adalah menonton video pembelajaran yang diberikan dan ketika di dalam kelas adalah latihan soal dan memecahkan masalah. Dalam arti luas, kegiatan flipped classroom di luas kelas bukan hanya menonton video pembelajaran tetapi juga harus menjawab soalsoal latihan yang bersifat tertutup, dan ketika di dalam kelas dilakukan aktifitas tanya jawab serta pembelajaran kelompok untuk memecahkan masalah yang bersifat terbuka.

Memperhatikan proses pembelajaran flipped classroom maka penerapan flipped classroom diduga dapat menyelesaikan permasalahan yang dihadapi. Mahasiswa yang lambat memahami materi dapat memutar video pembelajaran berkali-kali di rumah. Sehingga permasalahan dosen yang kekurangan waktu dalam menjelaskan materi dapat teratasi karena proses memahami materi dilakukan di rumah oleh mahasiswa, bukan lagi di dalam kelas.
Waktu pertemuan di kelas dapat dimaksimalkan untuk mendiskusikan latihan atau persoalan yang lebih sulit dan beragam. Berdasarkan pemaparan di atas, penelitian ini dilakukan untuk mengetahui apakah ada pengaruh pembelajaran flipped classroom terhadap hasil belajar kalkulus integral mahasiswa pendidikan matematika Universitas Pasir Pengaraian.

\section{METODE PENELITIAN}

Penelitian ini merupakan penelitian semu atau quasi experiment. Quasi experiment merupakan desain penelitian yang mempunyai kelompok kontrol tetapi tidak berfungsi sepenuhnya untuk mengontrol variabel-variabel luar yang mempengaruhi pelaksanaan eksperimen (Kurniati, Muhandaz, dan Hamzah, 2017). Pada quasi experiment, subjek tidak dikelompokkan secara acak, tetapi peneliti menerima keadaan subjek seadanya. Hal ini dilakukan dengan pertimbangan bahwa subjek tersebut telah ada sebelumnya pada kelas mereka masing-masing dan tidak memungkinkan untuk melakukan pengacakan ulang. Adapun desain penelitian yang digunakan adalah Randomized Control Group Posttest Only Design (Sugiyono, 2010).

Penelitian ini melibatkan dua kelas, yaitu kelas eksperimen yang diberikan pembelajaran flipped classroom dan kelas kontrol yang diberikan pembelajaran langsung. Variabel terikat pada penelitian ini adalah hasil belajar kalkulus integral mahasiswa yang diukur melalui tes uraian. Variabel bebas pada penelitian ini adalah model pembelajaran yang digunakan, yaitu pembelajaran flipped classroom pada kelas eksperimen dan pembelajaran langsung pada kelas kontrol.

Penelitian ini dilaksanakan pada semester genap tahun ajaran 2017/2018 di program studi pendidikan matematika Universitas Pasir Pengaraian. Pelaksanaan penelitian dilakukan selama 7 pertemuan pembelajaran dan 1 pertemuan sebagai posttes. Posttes diberikan untuk menentukan apakah terdapat perbedaan rata-rata penguasaan materi kalkulus integral antara kelas eksperimen dan kelas kontrol.

Populasi pada penelitian ini adalah mahasiswa yang mengambil mata kuliah kalkulus integral yang terdiri dari $90 \%$ mahasiswa semester dua program studi pendidikan matematika Universitas Pasir Pengaraian. Jumlah populasi pada penelitian ini sebanyak 27 orang yang terbagi dalam dua kelas. Pemilihan sampel menggunakan teknik sampling jenuh. Kelas pertama terdiri dari 21 mahasiswa, sedangkan kelas kedua terdiri dari 6 
mahasiswa. Karena pembelajaran flipped classroom yang dirancang memerlukan pembentukan kelompok untuk berdiskusi maka kelas yang dipilih untuk penerapan pembelajaran flipped classroom adalah kelas pertama dengan jumlah mahasiswa 21 orang. Kelas kedua kurang memungkinkan untuk penerapan pembelajaran flipped classroom karena jumlah mahasiswa yang terlalu sedikit sehingga kurang efektif untuk pembagian kelompok.

Instrumen pengumpul data pada penelitian ini adalah tes berupa soal uraian untuk mengukur hasil belajar materi kalkulus integral mahasiswa. Data hasil penelitian disajikan dalam bentuk tabel dan dianalisis dengan menggunakan uji statistik untuk menentukan perbedaan rata-rata hasil belajar antara kelas eksperimen dan kelas kontrol. Uji yang digunakan adalah uji normalitas dan uji mann-whitney.

\section{HASIL DAN PEMBAHASAN}

Hasil belajar mahasiswa materi kalkulus integral diukur melalui pemberian tes uraian yang dilaksanakan setelah mengikuti pembelajaran sebanyak 7 kali pertemuan. Hasil tes tersebut ditampilkan pada Tabel 1.

Tabel 1. Hasil Belajar Mahasiswa

\begin{tabular}{lcccl}
\hline Kelas & $\bar{x}$ & $x_{\min }$ & $x_{\max }$ & SD \\
\hline Eksperimen & 74,57 & 58,00 & 98,00 & 9,33 \\
Kontrol & 55,83 & 40,00 & 75,00 & 14,63 \\
\hline
\end{tabular}

Berdasarkan data pada Tabel 1 terlihat
bahwa rata-rata penguasaan materi kalkulus integral di kelas yang memperoleh pembelajaran flipped classroom lebih tinggi dibandingkan kelas yang mendapat pembelajaran langsung. Meski demikian, tidak ada satupun mahasiswa yang memperoleh nilai sempurna. Jika memperhatikan nilai simpangan baku, nilai pada kelas kontrol lebih beragam dibandingkan kelas eksperimen. Berdasarkan paparan ini dapat dinyatakan bahwa kelas eksperimen memiliki penguasaan materi kalkulus integral yang lebih baik dibandingkan kelas kontrol.

Untuk menentukan apakah perbedaan rata-rata kedua kelas tersebut signifikan atau tidak, maka perlu dilakukan uji statistik. Sebelum menentukan jenis uji yang digunakan, terlebih dahulu dilakukan uji prasyarat berupa uji normalitas dan uji homogenitas. Uji normalitas dilakukan untuk melihat apakah data berdistribusi normal atau tidak. Uji normalitas menggunakan Kolmogorov-Smirnov Test dengan bantuan software SPSS 25. Kriteria yang digunakan adalah tolak $\mathrm{H}_{0}$ jika Sig. $<0,05$.
Hasil uji normalitas diperoleh nilai Sig. 0,045 yang berarti $\mathrm{H}_{0}$ ditolak. Dengan demikian data tidak berdistribusi normal.

Karena data tidak berdistribusi normal, maka uji homogenitas tidak dilakukan. Uji perbedaan rata-rata yang digunakan adalah uji Mann-Whitney dengan kriteria pengujian yaitu tolak $\mathrm{H}_{0}$ jika Sig. $<0,05$. Hipotesis yang digunakan pada penelitian ini adalah: $\mathrm{H}_{0}: \mu_{1}=$ $\mu_{2}$ dan $\mathrm{H}_{1}: \mu_{1} \neq \mu_{2}$. Hasil uji mann-Whitney disajikan pada Tabel 2.

Tabel 2. Hasil uji Mann-Whitney

\begin{tabular}{lc}
\hline \multicolumn{1}{c}{ Keterangan } & Nilai \\
\hline Mann-Whitney U & 18,500 \\
Asymp. Sig (2-tailed) & 0,009 \\
\hline
\end{tabular}

Berdasarkan Tabel 2 dan kriteria pengujian maka ditarik kesimpulan bahwa $\mathrm{H}_{0}$ ditolak. Ini berarti terdapat perbedaan signifikan hasil belajar kalkulus integral antara kelas yang memperoleh pembelajaran flipped classroom dengan kelas yang mendapat pembelajaran langsung. Artinya, terdapat pengaruh pembelajaran flipped classroom terhadap hasil belajar kalkulus integral mahasiswa pendidikan matematika. Hasil belajar mahasiswa yang mendapat pembelajaran flipped classroom lebih tinggi dibandingkan hasil belajar mahasiswa yang mendapat pembelajaran langsung.

Temuan pada penelitian ini sesuai dengan temuan peneliti lain yaitu Pharamita dan Muchtar (2016) serta Pratiwi, Sahputra, dan Hadi (2017) yang menunjukkan bahwa hasil belajar siswa yang mendapatkan pembelajaran flipped classroom lebih baik dibandingkan yang mendapat pembelajaran langsung.

Terdapat beberapa faktor yang menyebabkan hasil belajar mahasiswa yang mendapatkan pembelajaran flipped classroom lebih baik dibandingkan pembelajaran langsung. Hal tersebut dapat dijelaskan dengan memperhatikan tahapan yang terdapat pada pembelajaran flipped classroom. Pada pembelajaran flipped classroom, proses pembelajaran dibalik penerapannya. Kegiatan penyampaian materi di ruang kelas dialihkan untuk mengerjakan latihan dan diskusi. Sementara kegiatan pekerjaan rumah berupa latihan-latihan soal yang biasanya dilakukan di luar ruang kelas (rumah) diganti dengan menonton video untuk memahami materi pertemuan yang akan datang.

Proses pembelajaran flipped classroom pada penelitian ini dilaksanakan melalui dua kegiatan utama, yaitu kegiatan di luar kelas dan kegiatan di dalam kelas. Kegiatan di luar kelas dimaksudkan untuk memahami materi 
pelajaran. Adapun kegiatan yang dilakukan di luar kelas ialah: 1) Dosen menyiapkan video pembelajaran yang akan digunakan mahasiswa untuk memahami materi. Video yang dibuat merupakan rekaman dosen menjelaskan materi di papan tulis seperti layaknya dosen menjelaskan materi di ruang kelas. 2) Video diberikan kepada mahasiswa. Teknis pemberian video ini yaitu melalui google drive. Dosen mengunggah video ke google drive lalu memberikan link untuk mengunduh video tersebut kepada mahasiswa. Melalui link tersebut, mahasiswa mengunduh video yang dibuat dosen. 3) mahasiswa menonton video di rumah atau dimana saja sebelum perkuliahan dimulai. Pada tahap ini mahasiswa diharapkan telah memahami materi dan diminta untuk mencatat hal-hal yang tidak dipahami pada materi yang dijelaskan dalam video.

Kegiatan di dalam kelas dimaksudkan untuk membahas materi yang tidak dipahami saat belajar di luar kelas serta mendalami pemahaman materi melalui latihan-latihan. Kegiatan di dalam kelas terdiri dari lima langkah utama, yaitu: pemberian kuis sebagai tes awal; berdiskusi; mengerjakan latihan; presentasi; dan menutup pelajaran.

Langkah pertama, pemberian kuis sebagai tes awal. Pada tahap ini dosen memulai dengan memberikan kuis untuk mengecek pemahaman awal mahasiswa tentang materi pada video yang telah mereka tonton. Selain sebagai informasi tentang pemahaman mahasiswa dalam memahami materi pada video, pemberian tes ini sangat penting untuk memotivasi mahasiswa agar menonton video sebelum pembelajaran dimulai. Kekhawatiran mahasiswa tidak bisa mengerjakan kuis akan mendorong mahasiswa untuk menonton dan memahami materi yang ada pada video. Setelah selesai kuis, dosen menyampaikan hasil kuis pertemuan sebelumnya kepada mahasiswa. Hal ini bertujuan untuk membuat mahasiswa terpacu mengejar nilai kuis yang lebih baik pada pertemuan berikutnya. Menyampaikan penilaian kepada mahasiswa dapat membuat mahasiswa terpacu untuk lebih bersemangat dan menjadi pembelajar mandiri (Kurniadi dan Purwaningrung, 2018).

Langkah kedua, berdiskusi. Setelah selesai tes awal, dosen memberikan kesempatan kepada mahasiswa untuk mengajukan pertanyaan tentang materi yang tidak dipahami dalam video yang telah diberikan. Dosen membuka sesi diskusi bersama mahasiswa. Pada pelaksanaan penelitian ini, beberapa mahasiswa mengajukan pertanyaan dan diberi kesempatan kepada mahasiswa lain untuk menjawab terlebih dahulu. Tahapan ini penting untuk membuat mahasiswa benar-benar memahami materi pelajaran pada hari tersebut. Kegiatan diskusi ini juga penting untuk mengklarifikasi kesalahpamahan mahasiswa dalam memahami materi pada video. Kesempatan yang diberikan kepada mahasiswa lain untuk menjawab pertanyaan temannya merupakan langkah penting dalam pelaksanaan pembelajaran ini. Hal itu memberikan motivasi kepada mahasiswa untuk benar-benar memahami materi agar dipertemuan berikutnya dapat menjawab pertanyaan dari teman-temannya yang belum mengerti.

Langkah ketiga, mengerjakan latihan. Setelah tidak ada pertanyaan lagi dari mahasiswa, dosen membagi mahasiswa kedalam 6 kelompok dengan anggota masing-masing 3-4 orang. Dosen memberikan soal untuk dijawab didalam kelompok masing-masing. Soal yang diberikan merupakan soal dengan beragam tipe dan tingkat kesulitan. Tahapan ini dilakukan untuk menambah pemahaman dan pendalaman materi bagi mahasiswa. Selama pengerjaan soal, dosen berkeliling untuk membantu kelompok yang mengalami kesulitan. Tahap ini memberikan kontribusi terhadap pemahaman dan pendalaman materi bagi mahasiswa. Melalui tahapan ini dosen dapat mengukur sejauh mana kemampuan mahasiswa dalam memahami materi. Tahapan ini sekaligus memberikan kontribusi terhadap pemahaman mahasiswa yang berakibat pada perbaikan hasil belajar mahasiswa. Sebagaimana hasil penelitian Ario (2015) yang menyatakan bahwa siswa yang terbiasa mengerjakan soal-soal latihan saat belajar akan relatif lebih mudah dalam menyelesaikan soal saat tes.

Langkah keempat, presentasi hasil kerja kelompok. Setelah selesai mengerjakan soal, perwakilan kelompok mempresentasikan hasil kerjanya. Dosen membuka sesi diskusi bagi kelompok lain yang ingin bertanya atau menyanggah jawaban kelompok penyaji. Sesi diskusi kembali dibuka untuk memastikan mahasiswa memiliki pemahaman konsep yang sama.

Langkah kelima, menutup pembelajaran. Dosen bersama mahasiswa mereview proses pembelajaran yang telah berlangsung dan membuat kesimpulan tentang materi pada hari tersebut. Pembelajaran ditutup dan dosen memberikan link video untuk pertemuan berikutnya. Dosen mengarahkan mahasiswa agar menonton video pembelajaran pertemuan 
berikutnya dan berjuang untuk memperoleh hasil kuis yang lebih baik.

Pelaksanaan pembelajaran flipped classroom seperti yang dipaparkan di atas memberikan kontribusi penting terhadap hasil belajar kalkulus integral mahasiswa. Hal ini bisa terjadi karena pelaksanaan pembelajaran flipped classroom memberikan waktu yang cukup banyak kepada mahasiswa untuk memahami materi pelajaran di rumah. Jika materi yang diberikan masih kurang dipahami, mahasiswa bisa memutar video tersebut berulang kali. Hal ini berbeda dengan kelas pada pembelajaran langsung. Dosen menjelaskan materi satu kali dan tidak mengulangnya berkali-kali. Dosen hanya bisa mengulangi bagian tertentu jika mahasiswa bertanya. Pengulangan materi di kelas juga tidak bisa dilakukan mengingat waktu yang terbatas. Ini adalah salah satu kelebihan pembelajaran flipped classroom yang menjadi salah satu penyebab hasil belajar mahasiswa lebih baik dibanding kelas pembelajaran langsung.

Sebelum pertemuan di kelas, mahasiswa di kelas flipped classroom telah membawa bekal pemahaman tentang materi yang akan dipelajari. Hal inilah yang menjadi perbedaan utama dengan kelas pada pembelajaran langsung. Pada kelas yang menggunakan pembelajaran langsung, mahasiswa memasuki pembelajaran dengan pengetahuan tentang materi yang masih sedikit dan bahkan belum mengetahui apa-apa. Hal ini karena karakteristik mahasiswa yang menjadi subjek penelitian ini yang tidak mau belajar terlebih dahulu sebelum perkuliahan dimulai. Mahasiswa baru mengenal dan mulai memahami materi ketika telah di kelas melalui penjelasan dosen. Hal ini tentu memberikan pengaruh yang berbeda. Mahasiswa yang memasuki kelas dengan bekal pemahaman yang sudah cukup tentu lebih baik dibandingkan mahasiswa yang memasuki kelas dengan bekal pemahaman yang masih kurang atau bahkan belum ada. Hal ini lah yang menjadi salah satu penyebab terdapatnya perbedaan hasil belajar kalkulus integral antara mahasiswa yang mendapat pembelajaran flipped classroom dengan mahasiswa yang mendapat pembelajaran langsung.

Faktor berikutnya yang turut memberikan perbedaan siginifikan pada hasil belajar mahasiswa yang mendapat pembelajaran flipped classroom dibandingkan mahasiswa yang mendapat pembelajaran langsung adalah keberadaan video yang dapat diputar berulang kali dan kapan saja. Hal ini sangat membantu mahasiswa jika lupa pada materi-materi sebelumnya. Mahasiswa dari kelas dengan pembelajaran flipped classroom dapat memutar kembali penjelasan materi melalui video yang mereka miliki. Hal ini tidak bisa dilakukan mahasiswa pada kelas pembelajaran langsung.

Meski memiliki banyak kelebihan, pelaksanaan pembelajaran flipped classroom pada penelitian ini juga mengalami kendala. Kendala pertama berupa hal teknis yaitu kesulitan mahasiswa dalam mendownload video karena ukuran video yang terlalu besar. Sebagian besar mahasiswa hanya mengandalkan wifi kampus untuk mendownload video, sementara wifi kampus sering tidak memadai untuk hal ini. Kendala teknis lainnya yaitu kesulitan mahasiswa dalam memutar video karena sebagian besar mahasiswa belum memiliki laptop. Jika diputar melalui HP maka tulisannya kurang jelas terlihat.

Kendala non teknis yang dialami adalah kesulitan mahasiswa jika terdapat penjelasan pada video yang tidak mereka pahami. Misalkan mereka tidak memahami materi pada menit ke 10. Setelah diputar lagi, tetap belum paham. Hal ini membuat mereka sulit untuk memahami materi pada menit-menit berikutnya, karena penjelasan menit berikutnya merupakan kelanjutan dari materi menit sebelumnya. Untuk kondisi seperti ini mahasiswa menyatakan bahwa mereka lebih senang diajarkan di kelas, karena jika tidak paham maksud suatu kalimat, mereka bisa langsung menanyakannya pada saat itu juga.

\section{SIMPULAN}

Hasil penelitian dan uji statistik yang dilakukan memberikan kesimpulan bahwa terdapat pengaruh pembelajaran flipped classroom terhadap hasil belajar materi kalkulus integral mahasiswa pendidikan matematika. Pengaruh ini disebabkan oleh proses pembelajaran flipped classroom yang memberikan waktu lebih panjang kepada mahasiswa untuk memahami materi pelajaran serta keberadaan video pembelajaran yang membuat mahasiswa bisa memutarnya berulangkali jika mereka lupa dengan materi yang lalu. Secara umum pembelajaran flipped classroom terdiri dari aktifitas di luar kelas dan di dalam kelas. Kedua aktifitas ini sama pentingnya dan harus berjalan dengan baik untuk memperoleh hasil yang maksimal. Meski memiliki kelebihan, penerapan pembelajaran flipped classroom juga bisa berpotensi menimbulkan beberapa kendala. Peran guru sangat penting dalam mengatasi kendala yang 
ada demi kesuksesan pelaksanaan pembelajaran flipped classroom.

\section{UCAPAN TERIMAKASIH}

Penulis ucapkan terimakasih kepada DRPM Kemenristekdikti yang telah membiayai penelitian ini melalui skema Penelitian Dosen Pemula 2018. Penulis juga mengucapkan terimakasih kepada segenap tim Pengelola Jurnal Anargya yang telah memberikan kesempatan kepada penulis untuk mempublikasikan karya ilmiahnya.

\section{DAFTAR PUSTAKA}

Ario, M. 2015. The Application of Mathematical Reasoning and Habits of Mind Through the Problem-Based Learning and Discovery Learning. Edusentris, 2 (1) : 34 - 46.

Ario, M. 2017. Profil Penguasaan Materi Matematika Sekolah Mahasiswa Pendidikan Matematika Semester VI. Aksioma, 6 (3) : 385-392.

Bioshop, J.L and Verleger, M.A. 2013. The Flipped Classroom: A Survey of the Research. Atlanta: 120th ASEE Annual Conference \& Exposition.

Chandra, F.H dan Nugroho, Y.W. 2016. Peran teknologi video dalam flipped classroom. Dinamika Teknologi. 8 (1) $: 15-20$.

Fahrudhin, A.G., Zulianan, E., dan Bintoro, H.S. 2018. Peningkatan Pemahaman Konsep Matematika melalui Realistic Mathematic Education Berbantuan Alat Peraga Bongpas. Anargya: Jurnal Ilmiah Pendidikan Matematika, 1 (1): $14-20$.

Kurniadi, G. dan Purwaningrum, J.P. 2018. Kemampuan Pemahaman Matematis Siswa melalui Discovery Learning Berbantuan Asesmen Hands on Activities. Anargya: Jurnal Ilmiah Pendidikan Matematika, 1 (1): 8 - 13.

Kurniati, A., Muhandaz, R., dan Hamzah, F.A. 2017. Pengaruh Penerapan Metode Pembelajaran Kelompok Buzz terhadap Kemampuan Komunikasi Matematika Siswa. Suska Journal of Mathematic Education, 3 (2) : 111 - 118.

Marhamah. 2016. Kompetensi Profesional Guru Matematika. Jurnal Dosen Universitas PGRI Palembang Edisi 4. http://www.univpgri-palembang.ac.id/e_ jurnal/index.php/ prosiding/article/view/518 diakses 5 Agustus 2018.
Noviarny, D.A., Murtono, dan Ulya, H. 2018. Model Think Talk Write Berbantuan Media Monomat Meningkatkan Kemampuan Komunikasi Matematika Siswa Sekolah Dasar. Anargya: Jurnal Ilmiah Pendidikan Matematika, 1 (1): $21-28$.

Pharamita, W. dan Muchtar, B. 2016. Pengaruh Model Flipped Classroom dan Sikap Siswa terhadap Hasil Belajar Ekonomi. Jurnal Kajian Pendidikan Ekonomi, 3 (1) : 37-50.

Pratiwi, A., Sahputra, R., dan Hadi, L. 2017. Pengaruh Model Flipped Classroom terhadap Self-Confidence dan Hasil Belajar Siswa SMAN 8 Pontianak. Jurnal Pendidikan dan Pembelajaran, 6 (11): 1-13.

Ridha, M., Setyosari, P., dan Kuswandi, D 2016. Pengaruh flipped mastery classroom terhadap perolehan hasil belajar kognitif mahasiswa. Jurnal Pendidikan: Teori, Penelitian, dan Pengembangan. 1 (4): 655 - 661.

Sugiyono. 2010. Metode Penelitian Pendidikan Pendekatan Kuantitatif, Kualitatif dan $R \& D$. Bandung: Alfabeta.

Undang-undang Nomor 14 Tahun 2005 tentang Guru dan Dosen. 
